\title{
Renegotiating quality TV in the Swedish press
}

\author{
American serial television and Sweden's \\ post-monopoly television landscape
}

\author{
Joel Frykholm
}

Centre for Languages and Literature, Film Studies, Lund University, Sweden

\begin{abstract}
In this article, I explore the reception of American "quality" serial television in Sweden from 1999 to the mid-2010s. My analysis includes how cultural critics and journalists writing for Sweden's leading newspapers conceptualised American serial television as "quality TV" and as legitimate "art", and it charts the ways in which these discourses relate to the reconfiguration of Swedish television from public service monopoly to niche-oriented multichannel system. The analysis uncovers a process of cultural consecration that was based on comparisons with already consecrated art forms, applications of authorship discourses that promote certain individuals as genius television auteurs, and deployment of critical protocols borrowed from literary criticism - all in service of pre-established cultural hierarchy and "good taste". This article also highlights the ubiquity of American quality serial television across the Swedish television landscape, which suggests that such programmes represent both a niche product and a mass phenomenon with extensive reach and multidimensional appeal.
\end{abstract}

Keywords: American serial television, quality TV, Swedish television culture, cultural journalism, cultural consecration

\section{Introduction}

American serial television has been a staple of Swedish broadcasting from the beginning (Thorslund, 2018). But the wave of American "quality TV" that emerged around the turn of the millennium has brought the excitement for this form of popular entertainment to new heights. Cultural critics, television aficionados, and audiences have enthusiastically embraced shows ranging from The Sopranos (HBO, 1999-2007) and Mad Men (AMC, 2007-2015) to Homeland (Showtime, 2011-) and House of Cards (Netflix, 2013-2018) - to name just a few.

While some such shows have attracted sizable Swedish audiences and others mere slices of the population, as an aggregated cultural phenomenon, they have had remarkable impact. They have stimulated new viewing habits, ignited debates about television,

Frykholm, J. (2021). Renegotiating quality TV in the Swedish press: American serial television and Sweden's post-monopoly television landscape. Nordicom Review, 41(1), 59-78. https://doi. org/10.2478/nor-2021-0012 
and influenced discourses and practices within tourism, cooking, cocktails, fashion, and interior design. American television has also become a favourite conversation piece. Twenty years ago, Swedes who claimed to "never watch TV" were still counted among the most highly cultivated citizens around; nowadays, lacking knowledgeability about serial television can be a social stigma.

It also used to be the case, dating at least back to the days of silent cinema, that the influx of American popular culture to Sweden was perceived as a dangerous manifestation of Americanisation - a term associated with fears of cultural imperialism, debasement, homogenisation, trivialisation, and vulgarisation (Lagerkvist, 2001). Not so with prestige serial television.

\section{Research questions, empirical focus, and methodological considerations}

With this article, I seek to make scholarly sense of this multifaceted process of cultural renegotiation. My gateway into the issue consists of journalistic and critical discourses in Sweden's leading newspapers. More specifically, I zoom in on two interrelated questions: 1) How have critics and cultural journalists writing for these papers framed American television series as quality TV? 2) What language, tropes, strategies, and modes of criticism have they relied on to conceptualise American television series as legitimate art?

Let us immediately acknowledge that journalistic discourses represent merely one set of cultural intermediaries involved in the "national mediation" of global culture (see Antoniazzi \& Barra, 2020), so what follows is not an exhaustive account of the entire process of localisation, but a more narrowly focused study. Neither is it an account of the critical reception generally, but of institutionalised criticism specifically. This choice might seem odd given the ongoing "de-professionalisation" and "participatory turn" of cultural criticism - the proliferation of "amateur" criticism across the digital mediascape and the concomitant diminishing of the authority and impact of professional critics (regarding the Nordic region, see Gripsrud, 2017; Kristensen \& Riegert, 2017). The point is well taken, but as Purhonen and colleagues (2019) point out, even though a variety of actors are involved in processes of cultural mediation, cultural journalists are nevertheless significant cultural intermediaries. Indeed, in the time period I address, the daily papers - especially their culture sections - still functioned as a clearinghouse for the wider public conversation about television and was still endowed with considerable authority in mediating a common-sensical, or hegemonic, understanding of what television culture is. This is especially true for newspapers that circulate nationally or cater primarily to readerships in Sweden's three largest metropolitan areas - Stockholm, Gothenburg, and Malmö - hence, I concentrate on these.

I culled the empirical material from the database Mediearkivet (owned by Retriever Sverige AB) through a series of keyword searches that resulted in a total number of 4,673 unique articles and items. The search process can be described as partly strategic (privileging drama series with an established "quality" reputation) and partly arbitrary, and the resulting dataset is neither exhaustive nor representative. But the search process produced the desired outcome, which was a collection of material large enough to offer an overview of the discourse from which salient patterns could be inductively identified and then made subject to a hermeneutical process aimed to produce new knowledge about the specific case and context (see Appendix 1 for details about the search terms and process). 
Each keyword search yielded a number of hits that were exported to RTF and PDF files. I first processed these files manually to remove irrelevant hits (ads for television hardware marketed as "quality TV sets" were the typical case) and to identify keywords and phrases that could then be connected to categories and themes. The latter were partly openly induced from the material, partly pre-set by my interest in articulations of 1) specific components of televisual "quality" and artistic excellence; and 2) connections between quality TV and other cultural forms. To illustrate, a category such as "comparisons between serial TV and film" was pre-set, whereas a category such as "TV criticism as fandom" was induced from the material. A broad category such as "quality TV characteristics" was pre-set, whereas associated subcategories such as "authorship discourses" or "conceptions of realism" emerged inductively.

I also merged the RTFs into one file including the entire corpus that could be used for simple searches across the material, which further facilitated the mapping of tropes and categories. The RTFs were also plugged into TextSTAT, a freeware application for simple text analysis, to measure word frequency, but I found the results mostly unhelpful both in terms of thematic and categorical pinpointing and further analysis.

The subsequent step involved hermeneutical movements between the empirical material, relevant scholarship (mostly from the field of television studies), and the research questions. One outcome was a gradual, deliberate, and necessary obscuration of much of the plurality and polyphony of the material, as larger, salient discursive patterns came into view. Two things stood out: first, there was extraordinary energy spent on framing serial television as legitimate art; second, there was a gradual discursive shift after 2012, at which point an aesthetic disposition toward serial television began to give way to a discourse connecting serial television to wider discussions about commercial streaming and online television. I address the post-2012 discursive shift elsewhere (Frykholm, in press). Here, I keep the focus on the cultural ascendance of American serials in Sweden and how this process relates to the transformation of Swedish television from public service monopoly to multichannel system.

My presentation of the analysis does not adhere strictly to the conventions of the standardised research article. For example, the dialogue with existing literature is integrated into the analysis rather than presented in a separate review, and there is no clearcut division between "results" and "discussion". With that said, the reader should have no problems following the line of reasoning or assessing the strength of the argument.

The remainder of the introduction previews my main findings and explains their significance in relation to existing research. Two analytical sections follow, one dealing with quality discourses, the other with legitimation discourses. A brief discussion about the distribution of American serial television in Sweden provides an additional interpretative frame and leads up to the conclusion.

\section{Basic findings and their significance in relation to previous research}

I am not the first to connect journalistic discourses on American quality serial television to a process of cultural consecration - similar analyses have been carried out from American and British, as well as Nordic, horizons (Anderson, 2009; Kristensen et al., 2019; Newman \& Levine, 2012; Rixon, 2011). My findings agree particularly strongly with Newman and Levine (2012). This includes the general conclusion that the legiti- 
mation of American serial television in Swedish newspapers has proceeded through negation, where ordinary television programmes, conventional ways of watching television, or, indeed, “'television' as it has long existed” (Newman \& Levine, 2012: 2), feature as the delegitimated, denigrated, rejected "other". Many readers may also find specific discursive tropes and strategies familiar, including comparisons with already consecrated art forms, applications of authorship discourses that promote certain individuals as genius television auteurs, and widespread deployment of critical protocols borrowed from literary criticism. These legitimation strategies, and their basis in what I would describe as anti-televisual sentiment, have produced a restricted approach to television - the discursive silence on issues that relate to the commercial foundations of American quality TV is particularly noteworthy - and contributed to the perpetuation of cultural hierarchies and dominant taste regimes, which is the exact opposite of the progressive destabilisation of cultural categories to which critics themselves often argued they were contributing.

The many points of accord between the Swedish case and what we already know from previous scholarship indicate that Newman and Levine (2012) were on to something when they hypothesised that legitimation discourses - much like the American television series they talk about - circulate globally. However, we should expect a degree of variation depending on the particular dynamics between local, national, and global that pertain to different locations. With regard to Sweden, we must consider the breakdown of the public service monopoly on television and the subsequent emergence of a multichannel system, a process that resonates with developments in other countries, but that partly follows its own logic and forges a television culture that is locally specific. Hence, contextual remarks are interwoven with the analysis of discourses, and the context is further enlarged in the section bridging the analysis and conclusion.

Finally, a clarification concerning quality TV - why privilege this term? The main reason is that Swedish critics habitually used this label, and that a certain type of American serial television hereby came to feature prominently in debates about quality TV that offer a vivid illustration of Swedish television's transition into a post-monopoly landscape. Approaching the term in this manner - as simultaneously a discursive trope and useful heuristics - I deliberately sidestep much of the polemics that has surrounded its status in television studies. The term has been deployed in this academic branch at least since the 1980s in studies of presumably extraordinary programmes, from Feuer and colleagues' (1984) study of MTM, via Thompson's (1997) book - Television's Second Golden Age: From Hill Street Blues to ER - to more recent investigations of quality TV of the HBO premium cable ilk (see, e.g., McCabe \& Akass, 2007). ${ }^{1}$ For some - for example, Newman and Levine (2012) - the problem with scholarship on quality TV (whether or not by that name) is the risk of contributing to an uncritical celebration of certain programmes at the expense of others, and at the expense of scholarly engagement with television in a more comprehensive and inclusive sense. For others - for example, Mittell (2015) - the problem with quality TV is its lacking use-value as an aesthetic concept. Anti-legitimation arguments à la Newman and Levine, Mittell (2015: 215) argues, tend to bracket off aesthetic issues altogether - hence his poetics of "complex TV" as an alternative approach meant to avoid "the categorical sweep" of both sides. My point is not to engage in these debates about the place of aesthetic analysis and evaluative criticism in television studies (see also Dasgupta, 2012; Johnson, 2007; Logan, 2016), 
or in the scholarly conversation about serial television, genre, and gender (see, e.g., Kackman, 2008; Mittell, 2015), but to make clear that this article's aim is to explore quality TV not as an aesthetic category, but as a label of distinction to be deconstructed and demystified - in this case, within the specific context of Swedish television culture.

\section{Analysis of quality discourses}

The discourse on quality and television contains multiple strands (see Brunsdon, 1990). The long-dominant one in a Swedish context, judging by the material studied for this article, postulated a privileged relationship between quality and public service. Many critics tended to reserve the quality label for programmes stemming from public service sources, and many perceived the BBC as a quality brand. Even more shared the belief that the Swedish public service broadcasting company Sveriges Television (SVT) had a special task of providing Swedes with quality TV (see, e.g., Hallert, 2000; Skawonius, 2000). The exact parameters of this special task were up for debate, as the issue was inextricably linked to a larger political struggle over the role of public service broadcasting. A bit simplified, one CAMP endorsed a model of public service television as a provider of a wide range of programming - from culture programmes for niche audiences to light entertainment for the masses - offering the "best" in each category (see, e.g., Lindstedt, 2000). The other camp argued that public service television should supply quality programmes that were socially and culturally valuable, but unlikely to be produced in sufficient numbers within the framework of commercial television (see, e.g., Expressen, 1999).

Neither side provided much room for American television fiction within the category of quality TV. This began to change in 2001. The Sopranos premiered on SVT in October 2000 and quickly proved to be a hit with Swedish viewers and critics (Björkman, 2000; Expressen, 2001; Panas, 2000). ${ }^{2}$ Critics embraced it as a great show, but initially in spite of, rather than thanks to, its origins in the American television industry. Indeed, some perceived the show to have more in common with a British quality tradition. More typically, however, the cultural value of The Sopranos was not perceived to derive from television, but from a resemblance to cinema. One critic, writing on the occasion of the Swedish premiere of season two in January 2001, combined these two perspectives: "The Sopranos is like a mix of Martin Scorsese's genre masterpiece 'Goodfellas' and a British quality TV series" (Peetre, 2001). ${ }^{3}$ Later that year, pop culture critic Jan Gradvall (2001) reversed the national hierarchy, arguing that British television had stagnated, whereas American serial television was in the midst of a creative revival.

Writers around this time tended to tie up premium cable shows and network series in the same quality-TV bundle, in spite of formal and other differences, but by 2003, a discourse linking quality specifically to HBO products had surfaced in Sweden. Already in this emergent phase, the company was often referred to as "the American quality TV channel HBO" (Gentele, 2003) or as a brand that had become "synonymous with quality" (Pressens Mediaservice, 2005). Around 2007, Swedish newspapers began to popularise the idea of a golden age of serial television (see, e.g., Nordström, 2007; Virtanen, 2007). HBO usually received the credit: "HBO started television's so-called new golden age [...] with series such as The Sopranos, Six Feet Under, and Sex and the City" (Fjellborg, 2008). Another journalist declared that "God's gift to television is spelled with three letters: HBO" (Larsson, 2009). 
Accordingly, the canon of quality serial television that emerged gravitated around HBO productions, HBO showrunners, writers, and creators, and the HBO brand (for further examples, see Björnulfson, 2007; Claeson, 2010; Lindbom, 2011). Listing "classic HBO series" became standard practice: Svenska Dagbladet published one such list in August 2010 (Palm, 2010); Expressen presented a similar list a month later (Larsson, 2010), as well as the guide "Classic series: How HBO Revolutionised Your TV Set" later that same year (Brännström, 2010). Certain non-HBO productions, too, came to be regarded as instant classics, especially the AMC series Mad Men and, somewhat later, Breaking Bad (see, e.g., Hilton, 2009; Larsson, 2013; Oscarsson, 2014).

The discursive renegotiation of the concept of quality TV in Sweden, as sketched here, was closely linked to the transformation of Swedish television in the same period. Much of the process resembles what Lotz (2014) has framed as American television's transition into a "post-network" era - a confluence of industrial, technological, and cultural transformations that includes a reconfiguration of the audience (from mass to niches), new modes of distribution (from broadcasting to narrowcasting), new sociotechnological arrangements (from television sets in domestic settings to a variety of platforms, screens, and viewing spaces), and a reshaping of viewing practices (from linear to nonlinear; from appointment to on-demand), all of which interlock with a series of challenges to industrial practices and the design of media infrastructures. In the Swedish case, however, we must give a particularly strong emphasis to the role of governmentsponsored public service television. In the words of Swedish film and television scholar Leif Furhammar (2006), "In the beginning was public service". And for a long time, there was really nothing else for television viewers in Sweden. Regular broadcasting had started in 1956; a second channel was added in 1969. Some Swedes would eventually be able to set up their own satellite dish or sign up for cable television, but the great majority only had access to the two public service channels. By the late 1980s, however, technological developments exerted significant pressure on the monopoly. A major challenge came with the launch of TV3 on New Year's Eve 1987, broadcasting via satellite from London, hereby circumventing Swedish broadcasting laws.

Around the same time, there were movements afoot to issue a concession for terrestrial broadcasting of commercial television. The political conditions of possibility derived partly from a general push toward deregulation at this juncture, partly from the fact that many politicians simply ceded to the technological untenability of maintaining a monopoly on broadcasting. After some twists and turns, TV4 was granted the concession. TV4 was launched already in 1990, but emerged in 1992 as the main commercial alternative to SVT.

Additional channels became available via basic cable in the years that followed. At the time of writing, a default broadcasting schedule lists twelve Swedish channels, including the two main public service channels SVT1 and SVT2, TV4, and nine basic cable channels. Both SVT and TV4 also offer several niche channels. In addition, there are Swedish premium cable channels as well as an enormous variety of international channels available for anyone inclined to sign up via their local cable television provider. Cable television is often bundled up with broadband services, giving viewers access to all kinds of online television "portals" (Lotz, 2017); the most commonly used are commercial streaming services, including both local options and those that operate transnationally, such as Netflix, HBO, Disney, and Apple. 
In an increasingly diverse and commercially oriented Swedish television landscape, SVT still plays a central - yet significantly renegotiated - role, faced with ever-mounting pressure to compete for audiences. SVT's diminishing viewership in the post-monopoly landscape reflects a broader reconfiguration of the television audience, most notably its "fragmentation". Edin (2006) describes how Swedish television has moved from a unified model, via a two-channel system allowing for some choice within the parameters of public service, to a "centre-periphery" model that entails some forms of mainstream viewing but also allows for commercial alternatives and hence greater opportunities for customised viewing, and then, finally, gradually closer to a dispersal of the audience across channels and platforms to the point of extreme fragmentation. There is still some way to go to reach that point - television's mass appeal has not vanished completely. But Edin's (2006: 64) suggestion that the Swedish television landscape is "increasingly differentiated", that the viewing experience is becoming "less social and more individual", and that "a segmentation of the audience [...] is taking place in response to greater specialization of program output" held in 2006 and rings even more true today. Statistics about channel availability and viewer distribution across different channels shows that the trend Edin discussed continued in the years that followed (see Carlsson \& Facht, 2010, 2014; Facht, 2016; Facht \& Olsson, 2019).

Edin's analysis (see also Bjur, 2016) links "fragmentation" to "nichification". In Sweden as elsewhere (see, e.g., Lotz, 2014), television has largely transformed from a broadcasting medium addressing a national mass audience to an arena for a variety of agents catering to their respective niche. Indeed, following the collapse of the monopoly, SVT, too, has increasingly conceptualised its audience in terms of niche groups, and less and less as a national, social collective (Edin 2006), hereby potentially contributing to the dissolution of television's function as a "cultural forum" (Newcomb \& Hirsch, 1983; Newcomb, 2007) geared toward the engendering of shared viewing experiences and shared frames of reference for various public issues, debates, and concerns.

This reconfiguration of television into a niche medium creates the conditions of possibility for the surge in increasingly "complex" serial narration (Mittell, 2015) at a certain point in television history. And it allows American quality serial television, which does not necessarily reach anything close to a mass audience, to nevertheless become the medium's gold standard and most highly prized content. In the Swedish context, the same process also involved the emergence of American prestige series as a market solution to the problem of what constitutes quality TV. Previously dominant quality discourses had tended to either connect quality to the wider mission of a public service television to provide a broad range of socially and culturally valuable programmes to a mass audience, or to identify quality TV with narrower, special-interest items on SVT's menu. In both cases, quality TV was understood not as a market solution, but as compensation for a market failure, and in both cases, quality was linked to one public service ideology or another. Dislodging the notion of quality TV from the context of public service is not unique to Sweden. Andrews (2014) notes that in the UK, quality is increasingly discussed as an expected outcome of competition in a multichannel environment, not as a defence of public, civic, and cultural values in the face of commercialism.

But how does a new, market-oriented conception of quality correspond to a specific niche in the Swedish television landscape? If there is such a niche, much of it is apparently occupied by a certain type of product - "complex" serial narratives - and a set 
of production companies that make up a restricted field of cultural production within the television industry (see Akass \& McCabe, 2018). In Sweden as elsewhere, HBO has been the leading exponent of this subfield within television culture, a field which, as Akass and McCabe (2018) note, is largely defined by a collective belief in the HBO model of television seriality as legitimate art. In other words, the framing of American serial television as quality TV is intertwined with a more far-reaching legitimation discourse that conceptualises serial television as a traditional art object and that nourishes an "aesthetic disposition" (Bourdieu, 1984) toward these programmes. Indeed, this is precisely the type of discourse that dominated writing about American serial television in Sweden's leading newspapers up to roughly 2012.

\section{Analysis of legitimation discourses}

What were the key components of the newspapers' legitimation of American serial television as art? In terms of relatively concrete discursive clusters, my list includes an emphasis on, preference for, and valorisation of 1) high production values and professional standards, 2) strong writing, 3) individual authorship, 4) realism, and 5) "smart" or "intelligent" programmes. Let us look at some representative examples.

First, there are the recurring characterisations of quality series - HBO productions in particular - as "lavish" (see, e.g., Gelin, 2007; Lindén, 2008; Malmström, 2012) and "well-made" (see, e.g., Larsson, 2003; Lewenhagen, 2012). The implied correlation between budget and quality confirms the presence of a non-judgmental conception of quality in the sense of "the highest fixed cost incurred by networks in pursuit of the largest audience" (Caves et al., 2005: 19) that establishes a baseline for quality TV as art - an oftentimes necessary, but hardly sufficient, condition.

Second, we have the widely shared idea that a properly artistic series must be "well written". This particular expression appears time again in the material, from early encomiums on The Sopranos (Pehrson, 2003) to later pieces in which journalists pondered how carefully True Detective's creator, writer, and showrunner Nic Pizzolatto must have weighed every word to create such "powerful artwork" (Fjellborg, 2014). Many Swedish critics used specific examples of strong writing to make sweeping claims about television as a "screenwriters medium" (Gradvall, 2001); the "cultural dominance" of serial television as an effect of their "author- and script-driven" mode of production (Sandström, 2013); or television series as the "quality novels of our times" (Thente, 2010; for responses, see Croneman, 2010; Domellöf-Wik, 2010; Persson, 2010).

Third, discourses on strong writing usually emphasised not the writers' room (i.e., the collective, collaborative basis for much scripted television), but the individual authorship of specific writers, creators, and showrunners. The discursive construction of the television auteur along such lines is evident in ideas about shows such as The Sopranos and The West Wing as "clearly the work of one, single creator" (Gradvall, 2001), and in suggestions that "the strength and originality of 'Six Feet Under' or 'The West Wing' is the individual narrative voice, exempt from compromise. Just like in a novel" (Gradvall, 2013). As elsewhere (see, e.g., Anderson, 2009), David Chase, the creator of The Sopranos, provided a particularly useful model - Swedish critics habitually attributed the artistic merits of The Sopranos to Chase, sometimes even implying that a new era in television drama began when he "was allowed to make [The Sopranos]" (Thunman 
Sköld, cited in Spektra/TT, 2013), conjuring the stereotype of the artist struggling to express his creative vision as the dark forces of commerce collude against him.

Fourth, there are indications of a strong preference for a kind of realism based on features such as unconventionality, depth, complexity, and ambiguity, all of which are assumed to distinguish artistic serial television from mainstream television. Along these lines, critics have argued that American television series had "rewritten the rules of narrative", that shows like Mad Men had taught viewers never to trust the usual "dramatic Pavlovian bells" (Hellsten, 2013), and that HBO productions tended to flout "audiencepandering principles" (Peetre, 2001). The presumed effect of such inventiveness is an experience of unusual complexity and depth, and a form of serial narration that is somehow more true to life than normal television. One critic talked about a tendency in television drama "to linger with "the complicated", which possibly made it the "most important narrative form of our times" (Gezelius, 2013b). Others argued that shows like The Sopranos and Six Feet Under were "filled to the brim with complex characters" (Hultman, 2007), or that characters in serial television of the 2000s came across as "complex persons [...] with all the flaws and fallibilities that this entails" (Hellsten, 2009). For many, "complex characters" functioned as vehicles for a realism defined by its plausible depiction of the minor events making up everyday life - artistically powerful representations of what "an ongoing life actually feels like" (Hellsten, 2013) and of "all of the things that happen when you are waiting for life to begin" (Svensson, 2012).

Finally, there is the remarkably frequent characterisation of American quality TV as "smart" and "intelligent" (Arvidsson, 2006; Gelin, 2007; Hellsten, 2009; Lewenhagen, 2012; Nordström, 2007; Peetre, 2001; Thente, 2010). Along similar lines, critics suggested that television's widely used nickname "dumburken" (equivalent to "the boob tube" or "the idiot box") had become a misnomer (Häglund, 2003; Nordström, 2007; Palm, 2010). Newspapers also filled up with articles allegedly proving that contemporary television made viewers smarter by engaging them in advanced mental gymnastics (see, e.g., Gelin, 2005; Svensson, 2006).

On a general level of discursive production, the most striking feature of these legitimation discourses is the ways in which claims about serial television as legitimate art are based on an appeal to the cultural prestige of already consecrated art forms, most notably cinema and literature. With regard to the connections to cinema, the dominant conception of realism ascribed to artistic serial television by Swedish critics is remarkably similar to Bordwell's (1979: 57) description of how postwar art cinema "defines itself as a realistic cinema", evident in the display of "real" locations, "real" problems, and, most importantly, the use of "realistic" - that is, psychologically complex - characters". The critical emphasis on ambiguity and authorial expressivity also overlaps with Bordwell's definition of art cinema. However, Swedish critics treated "realism", "complexity", "depth", and so on, as universal artistic categories, not as importations from art cinema. I point to an implied analogy, then, rather than an explicit discourse on the relationship between serial television and cinema. The latter tended to consist of undifferentiated concepts organised hierarchically ("TV is now just as respectable a medium as cinema - or better") and vague allusions to quality serial TV as "cinematic" (a common trope in other national contexts, too; see Andrews, 2014).

Implicitly or explicitly invoked, cinema provides a historical model of how a oncederided form can ascend to cultural legitimacy. The distinction and cultural prestige of 
art cinema and quality serial television alike rests on their opposition to an assumed mainstream (Bordwell, 1979; see also Thompson, 1997: 12, for definitions of an earlier wave of quality TV as "better, more sophisticated, and more artistic than the usual network fare"). The construction of the television auteur can also be seen as a replication of the legitimation process cinema once underwent. As Newman and Levine (2012) note, in both cases, claims for cultural legitimacy rely on the construction of auteurs in a collaborative mass medium previously held to lack individual genius artists. And both cases support Bourdieu's suggestion that the "“charismatic ideology' of authorship [...] 'is the ultimate basis of belief in the value of a work of art"” (cited in Anderson, 2009: 37).

Auteurist discourses also represent one of multiple appeals to the cultural clout of the literary field in claims for the legitimacy of serial television. The pattern is familiar from other national contexts - Rixon (2011) notes that British television critics who treat serial television as art tend to operate in a "literary tradition" that places the emphasis on the text and the pen behind it, effectively treating the programmes as if they were "just like novels" (to paraphrase the afore-cited Gradvall, 2013).

Usually, the transfers of cultural prestige from the literary sphere to the field of television tended to reaffirm the cultural supremacy of the former. As one critic put it, "It would be a mistake to label these new, genuinely smart, TV series as literature. [...] But they borrow the best attributes of classic literary fiction, this is precisely what makes [them] so good" (Sandström, 2013). This particular critic holds a PhD in comparative literature from Lund University. The critic who talked about serial television as the "novel of our times" studied at the same department. The writer who suggested that television series were "just like novels", on the other hand, has no formal education at all. This indicates that the reproduction of cultural hierarchy - and more specifically the idea that all cultural capital must ultimately stem from the pen - is multi-sited, and nourished by critics of different stripes, employment situations, and educational backgrounds.

The literary field also provides ready-made models for television critics to conceive of their own role. Similar to how literary criticism separates the wheat (critics) from the chaff (ordinary readers), the framing of American serial television as unprecedently smart, deep, complex, and so forth, implies that special skills are required to appreciate these programmes, and to properly excavate and explicate their cultural significance. And the tools used for these excavations and explications - usually some combination of New Criticism and auteurism - are roughly the same as the conventional literary critic might have used. However, Swedish critics (at least obliquely) acknowledged a Bourdieuan twist, namely that cultural value is not a purely textual or authorial quality, but also produced through acts of distinction by those who have been afforded the authority to distinguish between artworks and everyday objects. Most notably, they repeatedly marshalled as irrefutable evidence of the elevated status of television that it had become a legitimate topic for articles in the culture sections of leading newspapers (see, e.g., Francke, 2013; Hellsten, 2009; Spektra/TT, 2013). That processes of distinction involve elements of contestation and power struggle was also (inadvertently) acknowledged through eruptions of turf war, where lines were drawn either between seasoned television aficionados and film and literary critics who are newcomers to television (Häglund, as cited in Yifter-Svensson, 2013), or between journalists and "Bourdieu wannabees" from the academy (Gradvall, 2013).

With respect to discourses on television's changing cultural status, it is important to note that many Swedish critics turned observations concerning a slice of programming 
into claims about the medium as a whole, eagerly arguing that "the television medium has been culturally upgraded on all levels" (Häglund, cited in Hultman, 2007), that "American television currently has higher status than American feature films" (Gelin, 2007), and that "TV has advanced on the cultural ladder" (Nordström, 2007). Even if we disregard the categorical mistake, such assertions represent an extreme simplification - or are simply not true. For one, anti-television sentiment clearly saturates the legitimation discourse. This is evident in the discursive distancing of quality serial television from standard televisual fare, to the point at which we were asked to think of it not primarily as television, but as cinema or literature. Part of this pattern was the strong tendency among Swedish critics to credit formal innovation and artistic merit to the influences of these venerated forms, and rarely if ever to the strategies of serial narrative developed specifically for television - a discursive repression (if not outright denigration) of the daytime soap, the cop procedural, the sitcom, and so on - or, indeed, of "television" as such. Here we see the equivalent of what Newman and Levine (2012: $30)$ noted in the American context: the legitimation of certain television programmes is often predicated on a "long-standing delegitimation of television", an "elevation of the medium [that] nonetheless supports anti-television discourses as holding fundamental truths" (for problematisation of "not-TV" discourses, see also Thorburn, 2009). Newman and Levine (2012) regard the silence on the daytime soap as a particularly significant omission, since this genre pioneered serialised narrative on television. ${ }^{4}$ But the point here is not to equate Breaking Bad with The Bold and the Beautiful - daytime soaps and "complex" series are neither exactly the same nor totally unrelated (see Mittell, 2015 ) - it is the relatively restricted, even antipathic, approach to television in Swedish newspapers that is significant. The same critique applies to the Swedish discourse on serial television as smart and intelligent. We may turn yet again to Newman and Levine (2012), who note that such tropes represent a self-similarity within a legitimation discourse that proceeds through negation, since brain-teasing programmes requiring highly active modes of viewing only stand out as such if we accept that the rest of television is precisely as dumb and passivising as implied in the derogatory terms (e.g., dumburken) that critics say they want to purge from the television critical lexicon.

Aside from the anti-television slant, we could also argue that the critical legitimation of serial television via auteurist discourses, intra-media comparison, and an insistence on realism, ambiguity, depth, and complexity as markers of artistic quality is not evidence of a challenge to cultural hierarchies, but - quite to the contrary - of the stronghold among cultural critics of what one Bourdieu-inspired television scholar (Bury, 2008: 196) refers to as "literary standards informed by bourgeois aesthetics". From this perspective, Swedish critics make up a cultural elite engaged in the ideological construction of their own preferences as purportedly universal or natural good taste, with a reproduction of taste, rather than its reevaluation, as the primary effect. As Bury (2008: 194) notes with regard to television's cultural status, "what has shifted is the positioning of texts on the high/low binary; the binary itself remains intact but redeployed to distinguish 'quality' popular texts deserving of literary treatment from those that are not" (other scholars have made essentially the same point - see, e.g., Akass \& McCabe 2018).

It would be unfair, however, to suggest that television criticism in Swedish newspapers has been completely co-opted by bourgeois aesthetics. Frequent invocations of passion, pleasure, and emotional ties as key to the appreciation of serial television (see, 
e.g., Häglund, as cited in Yifter-Svensson, 2013; Gradvall, 2013) indicates that there is room for fan reflections as well as traditional criticism. The construction of quality serial television as simultaneously an object of fandom and an object that meets the standards of bourgeois aesthetics does offer further evidence of a "considerable fluidity between elite and mass culture" that goes back at least to the 1960s (Harrington \& Bielby, 2001). Alternatively, we could argue that American quality serial television assumes a shape that is neither high nor low, but middlebrow, defined by its capacity to combine an appeal to legitimate culture with mass accessibility - a "massified form of high culture" (Guillory, 1995: 87), or a form that makes "high culture" accessible to a wide public (Rubin, 1992).

First and foremost, however, we are dealing with a cultural product developed for the purpose of maximising economic profit. As such, American quality serial television is a locus of contradictory forces with respect to its cultural positioning. The profit motive pushes toward a declassification of culture, in this case via products that are deliberately designed to attract as many different types of audiences as possible - from couch potatoes to cultural critics. But the reconfiguration of the audience from an imagined mass public to an assembly of niche audiences requires a reclassification of culture - hence the culture industry's campaign to make prestige serial television the cornerstone of an aristocracy of television.

Such economic determinants of the cultural status of quality TV - and of television in general - were usually obscured in the Swedish discourse, with some notable exceptions (see, e.g., Pehrson, 2003). Many critics pretended that HBO somehow escapes the otherwise all-encompassing commercial character of contemporary television, allowing customary celebrations of "creative freedom" to spill over into ill-founded, generalised claims about HBO being "less commercial" than other television corporations (Larsson, 2013) and free-standing from the conglomerate industry structure of which HBO is in fact an integrated part (Henriksson, 2003). Such misperceptions come as no surprise, as the recontextualisation of quality TV - a relocation of the televisual urinal to the art museum that removes it from the material world of its production - is part and parcel of making it subject to a process of cultural sacralisation. But they do signal a problematic adherence to an art-commerce binary opposition and an uncritical acceptance of HBO's propaganda about itself as a space where television auteurs operate untrammelled by commercial restrictions - especially since whatever creative autonomy afforded by HBO is at least partly motivated by a commercial logic that requires premium subscription services to provide uniquely distinct products, the kind that makes viewers willing to pay a substantial monthly fee (see, e.g., McCabe, 2013). Quality TV, as co-constructed by the television industry, critics, and audiences, is this product. Santo (2008: 20) suggests that the programmes are but one element of a larger equation within the economy of prestige: HBO sells cultural capital to its subscribers who are thus "elevated above the riffraff that merely consume television, a medium long derided as base and feminizing in an unabashed embrace of consumerism".

\section{The "quality niche" - enlarging the context}

Notwithstanding the potential influence of cultural journalists on Swedish television culture, their campaign to make serial television fit into the ready-made categories of 
already consecrated culture (to borrow a phrase from the late film critic Pauline Kael, 1969/1970) can only tell us so much about the location of American quality serial television in the Swedish television landscape. Let us briefly consider the paths of distribution that significantly shape the ways in which Swedish audiences experience such programmes. Here, we encounter an interesting dispersal across the television landscape. Some of the signature shows of prestige television, including The Sopranos, The Wire, and Six Feet Under, were initially broadcast by the public service broadcaster SVT. Its then director of drama explained in 2006 that even though domestically produced television drama was more popular, it was important for SVT to also offer shows such as the ones mentioned above, due to their "high [artistic] level" and their "influence on a lot of other [TV] drama" (cited in Collin, 2006). Meanwhile, two earlier HBO productions, $\mathrm{Oz}$ and Sex and the City - both relatively overlooked yet arguably still part of the same quality paradigm as the aforementioned examples - appeared on the ad-funded, entertainment-oriented TV3. Products offered by HBO's premium cable competitor Showtime have also been scattered across different types of channels: Homeland airing on SVT, Weeds on TV3, Shameless on Kanal 9, and Californication on TV4 - to name a few examples. TV4 - combining an ad-based revenue model with a degree of variety of programming and wide appeal, allowing it to compete quite successfully with SVT - has also been a main outlet for American network series considered special enough to earn a complexity or quality label, in spite of their roots in "ordinary" television, among them 24, Lost, and Arrested Development. When it comes to AMC attractions, Mad Men's Swedish run was divided between Kanal 5 and Kanal 9. Kanal 5's self-assigned mission is to provide television that is "more fun than anyone has ever accomplished before", a strict diet of pure televisual "candy" served up primarily to the 15-44 age group (cited in Grip, 2003: 49). Its sister channel Kanal 9 is currently branded as a channel that offers "uncomplicated" entertainment for men (Helander, 2014). Another critical darling of the AMC brand, Breaking Bad, was first broadcast in Sweden in 2008 on TV6, a sister channel to TV3 that targets young male viewers, but was quickly moved to TV8, another channel owned by the same corporation as TV3 and TV6 (Modern Times Group, which was split into two companies in 2018, MTG and Nordic Entertainment Group - the latter currently handles the TV business). TV8 started out in 1997 as an outlet for financial news and other "serious" content, but has since been revamped - most recently in 2015 - to focus almost exclusively on crime (true and fictional) (Rislund, 2015). By the end of season 2, Breaking Bad was off the Swedish air, and did not return until 2013, when Kanal 9 purchased the rights to broadcast the final eight-episode season (TT, 2013).

The reason Kanal 9 brought Breaking Bad back to the air was that there was an audience for it, made up of people who had accessed the show by means other than traditional broadcast. The launch of a local version of Netflix in late 2012 made Breaking Bad readily available for (legal) streaming in Sweden, which might have been particularly crucial in this case, but long before this, another viewing technology - the DVD box set - had helped popularise the consumption of complex American serial television in Sweden, as well as fostering binge-viewing habits that were carried over into the streaming era.

More research is required to determine the relative importance of broadcasting, DVD viewing, and streaming with respect to the circulation of American serial television in Sweden, and whether it is possible to discern a distinct niche audience for such programmes in the declassified haze of a commodified mass culture once based on selling 
and renting DVDs, now streaming. When it comes to distribution through broadcasting, we have seen that different forms of "quality" serial television were prized content for a variety of agents in the Swedish television industry - perhaps we should talk, then, about several distinct viewing formations and target groups rather than one singular "quality" audience. Alternatively, some channels might have used quality TV series to attract an audience that would otherwise not tune in. Here, we must admit that we simply do not know very much, and that we should avoid generalised assertions about the quality TV audience, including the relationship between class, taste, and aesthetics. We should also entertain the notion that quality serial television represents not so much a clearly defined niche as a more comprehensive phenomenon in television culture, a point of crystallisation for the medium's multifaceted transformation.

\section{Conclusion}

This article has detailed how cultural critics and journalists writing for the leading newspapers in Sweden have worked to conceptualise American serial television as quality TV and as a traditional art object. The quality discourses helped dislodge the notion of quality TV from the context of public service, a process that reads as an index of Swedish television's shift from public service monopoly to multichannel system. Meanwhile, the legitimation of serial television as art - to which the quality discourses are inextricably linked - made "television" recede into the background - there was lots of "quality", but little "TV". One root cause is the overinvestment in conventional cultural hierarchy: comparisons to literature or cinema and appeals to the cultural prestige of these venerated forms all too often resulted in a problematic disregard for the formal specificities and distinctive stylistic and narrative traditions of serial television. Another indication of the pledging of allegiance to well-established regimes of taste, and the reinforcement rather than destabilisation of long-held distinctions between "high" and "low", is the borrowing of critical protocols from literary criticism as a key strategy in the cultural consecration of serial television. At best, a discourse along these lines restricts the critical domain to a small range of sanctioned television programmes, viewers, and modes of viewing, offering little in terms of a comprehensive approach to the medium. At worst, it works to delegitimate much of what has long been, and still is, regarded as main features of television, both in terms of programming and modes and habits of viewing.

This analysis (which strongly aligns with Newman and Levine's account of legitimation discourses in the US) takes the form of a negative critique meant to reveal the long-dominant discourse on American quality serial television in Swedish newspapers for what it was: overly celebratory and severely limited in its approach to television culture, industry, and aesthetics. But I also want to stress the positive end points of my analysis, especially the value of deconstructing these discourses in order to explore the material realities of the television culture and industry in Sweden. Along these lines, the analysis shows that the surge of American serial television in Sweden correlates with the reconfiguring of television into an increasingly niche-oriented medium in the wake of the breakdown of the public service monopoly in the late 1980s. The exact location of American quality serial television in a niche-based television landscape, however, is not entirely clear. While constructed in the newspaper press as television for a cultural elite generally under the sway of bourgeois aesthetics, a look at the circulation of American 
quality TV series in Sweden indicates that this represents a niche within a niche, or one facet of a more comprehensive and complex cultural phenomenon.

Arguably, part of the complexity relates to what Lotz (2014) has diagnosed as the growing difficulty of studying television as a distinctly national experience. I am not referring to some wholesale makeover of Swedish television from national to global, or to a one-directional process of globalisation or Americanisation (terms that are overly general or otherwise problematic anyway) - or even to the more nuanced notion of "national mediation" (Antoniazzi \& Barra, 2020) - but to the fluidity and flexibility of an assemblage that in the case at hand is defined by the shifting relations between a nationally distinct media system, US-based content producers, transnational distributors, and universalised notions of art that seem to have reached a degree of global circulation, similar to the prestige programmes to which they are attached in promotional as well as critical discourses.

In recent years, newspapers have widened the scope of their interrogations of the location of American serial television in the Swedish television landscape. As I discuss elsewhere (Frykholm, in press), a discursive shift occurred after 2012, when the fervour to frame American serial television as extraordinary art began to diminish, and a process of rematerialisation kicked off via discussions situating such shows at the core of an emergent culture of commercial streaming and globalised, online television, on account of their presumed capacity to drive the mass affixation of eyes to streaming services like Netflix. Accordingly, the working assumption about the relevance of cultural journalists that I brought into this project has only been partly vindicated - the research shows that critical and journalistic discourses are just as reactive to the changing material realities of television as they are constitutive of the general conceptualisation of this medium and its products. In the long run, they are perhaps more effect than cause.

\section{Funding}

The research for this article was funded by a grant from Wahlgrenska Stiftelsen (Malmö, Sweden).

\section{Notes}

1. These titles represent one strand of a much wider scholarly conversation about television and "quality". First, the term is not limited to American serial television, but also features as a broader concept in discussions about European public service broadcasting. Second, there has been a mushrooming of scholarship that takes notions of quality TV originally conceived to address American television and then re-applies them to non-American contexts, so that we now have studies of Danish, Flemish, French, German, Israeli, Italian, Mexican, and Spanish vernacular versions of quality TV - to name a few examples (Bauman, 2018; Harlap, 2017; Jost, 2020; Krauß, 2018; Lavie \& Dhoest, 2015; Redvall et al., 2016; Smith, 2016). There is even a recent book that makes the case for a "renaissance" of European television fiction, akin to, or inspired by, what the editors (Barra \& Scaglioni, 2020: 2) call the "golden age" of American serial television. Other scholars have cautioned against a scholarly overemphasis on a certain kind of American series as the benchmark of quality due to the risk of "overshadowing the range of different conceptions and traditions of quality that exist in different televisual cultures" (Buonanno, 2013: 175).

2. The pilot episode of The Sopranos aired on SVT 2 on Friday, 6 October 2000 at 21:00 and attracted 945,000 viewers. These were impressive figures, according to commentators at the time, especially considering that the premiere took place during what journalists referred to as Swedish television's "super weekend" and the start of a "war for the viewers", involving season premieres of high-profile entertainment programs on all major channels. The Sopranos was slotted against TV4's Who Wants to Be a Millionaire? and the latter gathered an audience of 2.2 million. By January 2001 The Sopranos had been moved to a Sunday evening slot in SVT 1, and ratings had dropped to 735,000, still high for an American series, but not in the vicinity of the most popular programs, nearly all of which were domestic productions.

3. I have translated all quotations originally in Swedish into English. 
4. Debates about the relations between "quality" series and soaps tend to focus on gender issues, especially the extent to which the infatuation with "complex" series reinscribes a gendered hierarchy that pits soaps/ feminine/bad against quality series/masculine/good. It is possible that some similar pattern informs legitimation discourses in Swedish newspapers, but the question merits more attention than I can offer here. But let me make two observations that might be relevant in this context: 1) A significant number of articles in my material offer critical commentary on the gendered aspects of American quality TV, some targeting the programmes - typically on account of concentrating too much on "difficult, brooding men" - some targeting the critical discourse - typically on account of showing too much reverence for shows about "difficult men" and too little interest in other types of quality series (for one representative example of each, see Gezelius, 2013a; Hellsten, 2009); 2). Such gender critiques appear with greater frequency in the early 2010 s than in the initial phase of cultural consecration five-ten years earlier.

\section{References}

Akass, K., \& McCabe, J. (2018). HBO and the aristocracy of contemporary TV culture: Affiliations and legitimatising television culture, post-2007. Mise au point, 10. https://doi.org/10.4000/map.2472

Anderson, C. (2009). Producing an aristocracy of culture in American television. In G. R. Edgerton, \& J. P. Jones (Eds.), The essential HBO reader (pp. 23-41). Lexington, Kentucky: University of Kentucky Press.

Andrews, H. (2014). Television and British cinema: Convergence and divergence since 1990. Basingstoke: Palgrave Macmillan.

Antonioazzi, L., \& Barra, L. (2020). Global distribution and 'national mediations' of ready-made TV shows in foreign markets: An introduction to the Special Section. Journal of Popular Television, 8(3), 249-253. https://doi.org/10.1386/jptv_00022_2

Barra, L., \& Scaglioni, M. (Eds.). (2020). A European television fiction renaissance: Premium production models and transnational circulation. New York: Routledge. https://doi.org/10.4324/9780429326486

Bauman, R. (2018). Masculinity, melodrama, and quality TV: Reviewing La piovra. Journal of Italian Cinema \& Media Studies, 6(3), 209-222. https://doi.org/10.1386/jicms.6.2.209_1

Bjur, J. (2016). Tittarfrihet - på drift med tablå-tv [Freedom for viewers - adrift with scheduled television]. Nordicom Information, 38(2), 8-12. nordicom-information_38_2016_2_8-12.pdf

Bordwell, D. (1979). The art cinema as a mode of film practice. Film Criticism, 4(1), 56-64. https://www. jstor.org/stable/44018650

Bourdieu, P. (1984). Distinction: A social critique of the judgement of taste (R. Nice, Trans.). Cambridge, Massachusetts: Harvard University Press.

Brunsdon, C. (1990). Problems with quality. Screen, 31(1), 67-90. https://doi.org/10.1093/screen/31.1.67

Buonanno, M. (2013). The transatlantic romance of television studies and the 'tradition of quality' in Italian TV drama. Journal of Popular Television, 1(2), 175-189. https://doi.org/10.1386/jptv.1.2.175_1

Bury, R. (2008). Praise you like I should: Cyberfans and Six Feet Under. In M. Leverette, B. L. Ott, \& C. L. Buckley (Eds.), It's not TV: Watching HBO in the post-television era (pp. 190-208). New York: Routledge. https://doi.org/10.4324/9780203928868

Carlsson, U., \& Facht, U. (Eds.). (2010). MedieSverige 2010 [Media Sweden 2010]. Gothenburg: Nordicom, University of Gothenburg. https://www.nordicom.gu.se/sv/system/tdf/publikationer-hela-pdf/mediesverige_2010.pdf?file $=1 \&$ type $=$ node $\&$ id $=10294 \&$ force $=0$

Carlsson, U., \& Facht, U. (Eds.). (2014). MedieSverige 2014 [Media Sweden 2014]. Gothenburg: Nordicom, University of Gothenburg. https://www.nordicom.gu.se/sv/system/tdf/publikationer-hela-pdf/mediesverige_2014.pdf?file $=1 \&$ type $=$ node $\&$ id $=34558 \&$ force $=0$

Caves, R. E., with Guo, K., O'Gorman, C., Rosenberg, M. S., \& Wegener, R. J. (2005). Switching channels: Organization and change in TV broadcasting. Cambridge, Massachusetts: Harvard University Press.

Dasgupta, S. (2012). Policing the people: Television studies and the problem of 'quality'. NECSUS: European Journal of Media Studies, 1(1), 35-53. https://doi.org/10.5117/NECSUS2012.1.DASG

Edin, A. (2006). Times have changed: On the relationship between Swedish public service television and the viewing public. Nordicom Review, 27(2), 61-72. https://www.nordicom.gu.se/sites/default/files/ kapitel-pdf/242_edin_2.pdf

Facht, U. (Ed.). (2016). MedieSverige 2016 [Media Sweden 2016]. Gothenburg: Nordicom, University of Gothenburg. https://www.nordicom.gu.se/sv/system/tdf/publikationer-hela-pdf/mediesverige_2016_1. pdf?file $=1 \&$ type $=$ node $\&$ id $=37279 \&$ force $=0$

Facht, U., \& Ohlsson, J. (Eds.). (2019). MedieSverige 2019 [Media Sweden 2019]. Gothenburg: Nordicom, University of Gothenburg. https://www.nordicom.gu.se/sv/system/tdf/publikationer-hela-pdf/mediesverige-2019_facht_och_ohlsson.pdf?file $=1 \&$ type $=$ node $\&$ id $=40042 \&$ force $=0$

Feuer, J., Kerr, P., \& Vahimagi, T. (Eds.). (1984). MTM: “Quality Television”. London: BFI. 
Frykholm, J. (in press). From the extraordinary to the everyday: Discourses on American quality serial television in Sweden's leading newspapers and the breakthrough of streaming TV. New Review of Film and Television Studies.

Furhammar, L. (2006). Sex, såpor och krusbär - televisionen i konkurrens [Sex, soaps, and gooseberries competitive television]. Stockholm: Ekerlids förlag/Stiftelsen Etermedierna i Sverige.

Gripsrud, J. (2017). The cultural, the political and the functions of cultural journalism in digital times. In N. N. Kristensen, \& K. Riegert (Eds.), Cultural journalism in the Nordic countries (pp. 181-193). Gothenburg: Nordicom, University of Gothenburg.

Guillory, J. (1995). The ordeal of middlebrow culture. Transition, (67), 82-92. https://doi.org/10.2307/2935258

Harlap, I. (2017). Television drama in Israel: Identities in post-TV culture. New York: Bloomsbury. https:// doi.org/10.5040/9781501328923

Harrington, C. L., \& Bielby, D. (2001). Constructing the popular: Cultural production and consumption. In C. L. Harrington, \& D. Bielby (Eds.), Popular culture: Production and consumption (pp. 1-15). Malden, Massachusetts: Blackwell.

Johnson, C. (2007). Negotiating value and quality in television. In H. Wheatley (Ed.), Re-viewing television history: Critical issues in television historiography (pp. 55-66). London: I. B. Tauris.

Jost, F. (2020). What is a quality French series? Reflections on The Bureau. In L. Barra, \& M. Scaglioni (Eds.), A European television fiction renaissance: Premium production models and transnational circulation. New York: Routledge. https://doi.org/10.4324/9780429326486

Kackman, M. (2008, October 31). Quality television, melodrama, and cultural complexity. FlowTV. https:// www.flowjournal.org/2008/10/quality-television-melodrama-and-cultural-complexity

Kael, P. (1970). Trash, art, and the movies. In Going steady. Boston: Little Brown. (Originally published in Harper's Magazine, February 1969.)

Krauß, F. (2018). 'Quality series' and their production cultures: Transnational discourses within the German television industry. International Journal of TV Serial Narratives, 4(2), 47-60. https://doi.org/10.6092/ issn.2421-454X/8282

Kristensen, N. N., \& Riegert, K. (2017). Why cultural journalism in the Nordic countries? In N. N. Kristensen, \& K. Riegert (Eds.), Cultural journalism in the Nordic countries (pp. 9-26). Gothenburg: Nordicom, University of Gothenburg.

Kristensen, N. N., Hellman, H., \& Riegert, K. (2019). Cultural mediators seduced by Mad Men: How cultural journalists legitimized a quality TV series in the Nordic region. Television \& New Media, 20(3), 257-274. https://doi.org/10.1177/1527476417743574

Lagerkvist, A. (2001). Från kulturimperialism till hybriditet: en översikt över teorier och litteratur om kulturspridning [From cultural imperialism to hybridity: An overview of theories and literature on the dissemination of culture]. Stockholm: Arbetslivsinstitutet.

Lavie, N., \& Dhoest, A. (2015). 'Quality television' in the making: The cases of Flanders and Israel. Poetics, 52, 64-74. https://doi.org/10.1016/j.poetic.2015.08.006

Logan, E. (2016). "Quality television" as critical obstacle: Explanation and aesthetics in television studies. Screen, 57(2), 144-162. https://doi.org/10.1093/screen/hjw020

Lotz, A. D. (2014). The television will be revolutionized (2nd ed.). New York: New York University Press.

Lotz, A. D. (2017). Portals: A treatise on internet-distributed television. Ann Arbor, Michigan: Maize Books. http://dx.doi.org/10.3998/mpub.9699689

McCabe, J. (2013). HBO aesthetics, quality television and Boardwalk Empire. In J. Jacobs, \& S. Peacock (Eds.), Television aesthetics and style (pp. 185-198). London: Bloomsbury. https://doi. org/10.5040/9781628928327.ch-013

McCabe, J, \& Akass, K. (Eds.). (2007). Quality TV: Contemporary American television and beyond. London: I. B. Tauris. https://doi.org/10.5040/9780755696376

Mittell, J. (2015). Complex TV: The poetics of contemporary television storytelling. New York: New York University Press.

Newcomb, H. (2007). "This is not al dente": The Sopranos and the new meaning of "television." In H. Newcomb (Ed.), Television: The critical view (7th ed.) (pp. 561-578). New York: Oxford University Press.

Newcomb, H., \& Hirsch, P. M. (1983). Television as cultural forum: Implications for research. Quarterly Review of Film Studies, 8(2), 45-55. https://doi.org/10.1080/10509208309361170

Newman, M. Z., \& Levine, E. (2012). Legitimating television: Media convergence and cultural status. New York: Routledge. https://doi.org/10.4324/9780203847640

Purhonen, S., Heikkilä, R., Karademir Hazır, I., Lauronen, T., Fernández Rodríguez, C. J., \& Gronow, J. (2019). Enter culture, exit arts? The transformation of cultural hierarchies in European newspapers culture sections, 1960-2010. New York: Routledge. https://doi.org/10.4324/9781315183404

Redvall, E. N., Wille, J. I., \& Gemzøe, L. S. (2016). Danish television drama: Production, texts, audiences. 
Joel Frykholm

Kosmorama, 263. https://www.kosmorama.org/en/kosmorama/en/kosmorama-263-danish-televisiondrama-production-texts-audiences

Rixon, P. (2011). TV critics and popular culture: A history of British television criticism. London: I. B. Tauris.

Rubin, J. S. (1992). The making of middlebrow culture. Chapel Hill, North Carolina: University of North Carolina Press.

Santo, A. (2008). Para-television and discourses of distinction: The culture of production at HBO. In M. Leverette, B. L. Ott, \& C. L. Buckley (Eds.), It's not TV: Watching HBO in the post-television era (pp. 20-45). New York: Routledge. https://doi.org/10.4324/9780203928868

Smith, P. J. (2016). Dramatized societies: Quality television in Spain and Mexico. Liverpool: Liverpool University Press. https://doi.org/10.5949/liverpool/9781781383247.001.0001

Thompson, R. J. (1997). Television's second golden age: From Hill Street Blues to ER. Syracuse, New York: Syracuse University Press.

Thorburn, D. (2009). The Sopranos. In G. R. Edgerton, \& J. P. Jones (Eds.), The essential HBO reader (pp. 61-70). Lexington, Kentucky: University of Kentucky Press.

Thorslund, T. (2018). Do you have a TV? Negotiating Swedish public service through 1950s programming, “Americanization," and domesticity [Doctoral dissertation, Stockholm University, Sweden). http://www. diva-portal.se/smash/get/diva2:1221669/FULLTEXT01.pdf

\section{Empirical material cited}

Arvidsson, H. (2006, January 8). Tevekanalerna riktar blicken mot USA [The TV channels look toward the US]. Dagens Nyheter.

Björkman, A. (2000, October 9). Grattis Luuk - men tacka Mys-Persson [Congratulations, Luuk - but you can thank Mys-Persson]. Expressen.

Björnulfson, J. (2007, October 21). Sopranos startade ny våg av kvalitetsserier [The Sopranos started a new wave of quality series]. Göteborgs-Posten.

Brännström, L. (2010, October 20). Klassiska serier: Så revolutionerade HBO din tv-apparat [Classic series: This is how HBO revolutionsed your TV set]. Expressen.

Claeson, D. (2010, January 5). Störst i tv [Biggest on TV]. Göteborgs-Posten.

Collin, L. (2006, October 4). Svenskt drama populärast i tv [Swedish drama the most popular TV genre]. Svenska Dagbladet.

Croneman, J. (2010, June 10). Teve vs. litteratur [TV vs. literature]. Dagens Nyheter.

Domellöf-Wik, M. (2010, June 18). Att kokettera med bristfälligt vetande [Coquettish displays of lacking knowledge]. Göteborgs-Posten.

Expressen. (1999, December 18). Avskaffa tv-licensen [Abolish the TV license fee].

Expressen. (2001, January 18). Tv-toppen 8-14 januari [TV toplist January 8-14].

Fjellborg, K. (2008, July 18). Antihjältinnan tar över [The antiheroine takes over]. Aftonbladet, Klick! supplement.

Fjellborg, K. (2014, January 10). Ett mäktigt konstverk [A powerful artwork]. Aftonbladet, Nöjesbladet supplement.

Francke, M. G. (2013, March 30). Tillgången ger efterfrågan [Supply begets demand]. Sydsvenskan.

Gelin, M. (2005, June 9). Tv och spel gör oss smartare [TV and games make us smarter]. Svenska Dagbladet.

Gelin, M. (2007, April 1). Slutspel för Sopranos dirigent [Endgame for the maestro of The Sopranos]. Svenska Dagbladet.

Gentele, J. (2003, May 20). Skotten i Columbine som dramadokumentär [The Columbine shooting as drama documentary]. Svenska Dagbladet.

Gezelius, K. (2013a, August 16). En rörande biblisk patriark i tokstora kalsonger [A pitiful biblical patriarch in crazily oversized underwear]. Dagens Nyheter.

Gezelius, K. (2013b, April 12). Hög tid att städa undan de gamla stereotyperna [It's high time to clean out the old stereotypes]. Dagens Nyheter.

Gradvall, J. (2001, November 14). Vita huset vs. Sopranos: våga ta ställning i giganternas kamp [The West Wing vs. The Sopranos: Dare to take a stand in the battle of the giants]. Expressen.

Gradvall, J. (2013, January 23). Vår bästa tid är nu [Our best time is now]. Expressen.

Grip, L. (2003). Tittarögon: En rapport om vad som bestämmer TV-utbudet [Eyeballs: A report on the factors that shape the television program supply] Våldsskildringsrådets skriftserie nr. 30. https://www. statensmedierad.se/download/18.6cd9b89d14fefd0c4f5941c8/1443165336514/Nr-30-Tittar-ogon.pdf

Hallert, K. (2000, May 17). Gisslan på Filippinerna - trestjärniga tv-nyheter [Hostages in the Philippines three-star TV news]. Aftonbladet.

Helander, M. (2014, January 27). Sänder "okomplicerad" underhållning för män [Broadcasts "uncomplicated" entertainment for men]. Resumé. https://www.resume.se/kommunikation/tv/sander-okomplicerad-underhallning-for-man/ 
Hellsten, A. (2009, December 30). Serien som gjorde tv fint [The series that made TV respectable]. Sydsvenskan.

Hellsten, A. (2013, July 28). Tv-serierna har helt skrivit om reglerna för berättandet [TV series have completely rewritten the narrative rules]. Svenska Dagbladet.

Henriksson, K. (2003, May 7). Det är inte tv, det är HBO [It's not TV, it's HBO]. Svenska Dagbladet.

Hilton, J. (2009, July 13). På kontorstid [Office hours]. Expressen.

Hultman, J. (2007, September 23). Morgondagens tv är redan här [The TV of tomorrow is already here]. Sydsvenskan.

Häglund, K. (2003, February 14). Serierna som räddade tv [The series that saved TV]. Aftonbladet, Puls supplement.

Larsson, M. [Markus]. (2003, February 28). TV:s främsta framgångsfabrik [TV’s foremost success factory]. Aftonbladet.

Larsson, M. [Markus]. (2013, August 9). Tjack och adjö! [approx. "Thanks and goodbye - no more mething around!" but basically untranslatable - a pun on the expression, "tack och adjö", i.e., "thanks and goodbye", where "tjack", Swedish slang for amphetamines, substitutes for "tack"]. Aftonbladet.

Larsson, M. [Mats]. (2009, March 8). Jag är besatt av HBO:s tv-serier [I am obsessed with HBO’s TV series]. Expressen.

Larsson, M. [Mats]. (2010, September 19). TV-imperiets återkomst [The TV empire strikes back]. Expressen. Lewenhagen, J. (2012, September 4). Snart premiär: Stort sug när HBO lanserar sig på den svenska marknaden [Coming soon: Much excitement over HBO's launch in Sweden. Dagens Nyheter.

Lindbom, V. (2011, March 6). Polisserie med familjen i fokus [Police series with a family focus]. Dagens Nyheter.

Lindén, A. (2008, March 12). "24” bryter in i människors privatliv [24 breaks into people's personal lives]. Svenska Dagbladet.

Lindstedt, K. (2000, January 5). SVT vann tv-året 1999 [SVT finishes the TV year 1999 on top]. Aftonbladet.

Malmström, M. (2012, October 10). Den bitterljuva slutstriden [The bittersweet final battle]. Svenska Dagbladet.

Nordström, A. (2007, March 7). Dumburkens dödsdom [Death sentence of the boob-tube]. Expressen.

Oscarsson, M. (2014, January 17). Nya tider - nya film- och tv-sidor [New times - new section for film and television coverage]. Sydsvenskan.

Palm, E. A. (2010, August 20). Dramatisk vägvisare [Dramatic trailblazer]. Svenska Dagbladet, "K" supplement.

Panas, D. (2000, October 2). Nu startar tv-kriget - Aftonbladet granskar 'superhelgen' [The TV war begins Aftonbladet covers the "super weekend"]. Aftonbladet.

Peetre, B. (2001, January 21). En familj som alla andra [A family like any other]. Sydsvenskan.

Pehrson, L. (2003, June 5). Smekmånaden är slut för den amerikanska succékanalen HBO [The honeymoon is over for the American success story HBO]. Sydsvenskan.

Persson, M. (2010, June 5). Litteratur lördag [Literature Saturday]. Expressen.

Pressens Mediaservice. (2005, January 14). Hyllade serier i vårens tv [Acclaimed series in the springtime TV schedule].

Rislund, N. (2015, August 12). MTG bygger om TV8 [MTG reshapes TV8]. Dagens Media. https://www. dagensmedia.se/medier/rorligt/mtg-bygger-om-tv8-6087765

Sandström, D. (2013, April 11). Vinnaren är en social berättelse [The socially relevant story wins out]. Svenska Dagbladet.

Skawonius, B. (2000, November 29). BBC vill utmana Hollywood [BBC wants to challenge Hollywood]. Dagens Nyheter.

Spektra/TT. (2013, June 20). James Gandolfini skrev tv-historia [James Gandolfini made TV history]. Svenska Dagbladet.

Svensson, J. (2012, July 16). Toppen att det finns unga bortskämda tjejer som litar till sin kreativa förmåga [It's great news that there are spoiled young women who trust their creative abilities]. Dagens Nyheter.

Svensson, U. (2006, April 23). Tokig i TV? Bra, du blir smart [Crazy about TV? Good, it makes you smart]. Aftonbladet, Sunday supplement.

Thente, J. (2010, May 26). Medelklassens nya roman är här [The new novel for the middle class is here]. Dagens Nyheter.

TT. (2013, October 7). "Breaking Bad" visas i Kanal 9 [Breaking Bad will air on Kanal 9]. Svenska Dagbladet. Virtanen, F. (2007, October 6). Sorgligt få vill titta på bra tv [Depressingly few people want to watch good TV]. Aftonbladet.

Yifter-Svensson, F. (2013, December 7). Nytt magasin sätter fokus på tv-rutan [New quarterly magazine focuses on the TV screen]. Sydsvenskan.

(C) 2021 Nordicom and respective authors. This is an Open Access work licensed under the terms of the Creative Commons Attribution-NonCommercial-NoDerivatives 4.0 International Public licence (CC BY-NC-ND 4.0). To view a copy of the licence, visit https://creativecommons.org/ licenses/by-nc-nd/4.0/ 


\section{Appendix 1}

The Mediearkivet searches were carried out on two separate occasions: the first on 8 May 2014 (covering the date range 1 January 1999-30 April 2014) and the second on 21 January 2019 (covering the period 1 May 2014-31 December 2018). There were two sets of search terms.

The first set was built around the main term "kvalitets-TV" ["quality TV"] and included 7 search terms:

1. kvalitets-TV

2. kvalitetsteve

3. "amerikansk kvalitets-TV"

4. +amerikansk +tv-serie +kvalitet

5. +tv-serier + hbo + kvalitet

6. +tv-serie +hbo +kvalitet;

7. +amerikanska + tv-serier + hbo + kvalitet

Furthermore, the titles of nine American television series were used as main search terms, in combination with modifying terms according to the following form: "title of show" AND "name of network" OR tv-serie OR tv-serier OR kvalitet OR amerikansk. The following television series were included:

- The Sopranos

- The Wire

- True Detective

- Game of Thrones

- Breaking Bad

- Mad Men

- The Walking Dead

- Dexter

- Homeland

For the "quality TV" searches, the sources included all Swedish printed press [svensk tryckt press] whereas the series-specific searches were limited to two Stockholm-based morning papers (Dagens Nyheter and Svenska Dagbladet), two Stockholm-based evening tabloids with national circulation (Aftonbladet and Expressen), one Gothenburg-based morning paper (Göteborgs-Posten), one Malmö-based morning paper (Sydsvenskan), a free daily newspaper distributed in Stockholm, Gothenburg, and Malmö (Metro), and the leading national press and news agency, TT. After removing non-pertinent hits and adjustments for overlap, the total number of unique articles and items came to 4,673. 